\title{
Dual effect of Algerian propolis on lung cancer: antitumor and chemopreventive effects involving antioxidant activity
}

\author{
Hadjer Brihoum ${ }^{1 *}$, Mhamed Maiza ${ }^{3}$, Hafida Sahali ${ }^{4}$, Malika Boulmeltout ${ }^{1}$, Gillian Barratt ${ }^{2}$, Lamia \\ Benguedouar ${ }^{1}$, Mesbah Lahouel ${ }^{1}$
}

${ }^{1}$ Laboratory of Molecular Toxicology, Department of Natural and Life Science, Faculty of Science, University of Jijel, Algeria, ${ }^{2}$ UMR CNRS, Faculty of Pharmacy, University of Paris-Sud XI, ${ }^{3}$ Biochemestry Service, Jijel Hospital, Jijel, Algeria, ${ }^{4}$ Oncology Service, Jijel Hospital, Jijel, Algeria

\begin{abstract}
The purpose of our study was to divulge the antiproliferative effect of an ethanolic extract of Algerian propolis (EEP) in the human lung adenocarcinoma cell line (A549) and reveal the chemopreventive role against benzo(a)pyrene-induced lung carcinogenesis in albino Wistar rats. Cytotoxicity of EEP was evaluated using the MTT assay and cell adhesion in A549 cells. Moreover, rats were given $25 \mathrm{mg} / \mathrm{kg}$ of propolis for 5 days before induction of experimental lung cancer by a single intraperitoneal dose of 200 $\mathrm{mg} / \mathrm{kg}$ benzo(a)pyrene. Body weight, lung weight, lipid peroxidation, marker enzymes, and enzymatic and non-enzymatic antioxidants were estimated. The EEP demonstrated an inhibitory effect on proliferation of A549 at 24 and 72 hours in a dose-dependent manner and blocked adhesion of the cells by fibrinogen. Moreover, EEP reduced the oxidative stress generated by benzo(a)pyrene. The pre-treatment showed that enzymatic and non-enzymatic antioxidants increased and lipid peroxidation decreased. A histological analysis further supported these findings and showed a decrease in the number of side effects. These results are particularly important for both clinical applications of propolis and the possibility for its use as a potential chemotherapeutic agent.
\end{abstract}

Keywords: Algerian propolis/effects. Benzo(a)pyrene. Chemoprevention. Lung cancer. Oxidative stress.

\section{INTRODUCTION}

Lung cancer is a type of malignant tumor of lung tissue (Yang et al., 2016) and is considered to be one of the most significant diseases in respiratory medicine (Silva et al., 2007). Lung cancer is the leading cause of cancerrelated death in men and women worldwide, with about 1.8 million new cases each year (Siegel, Miller, Jemal, 2015). Several epidemiological studies have shown that exposure to polycyclic aromatic hydrocarbons (PAHs) can increase the risk of multiple cancers, such as those of the lung. One of these PAHs is benzo(a)pyrene (B(a) $\mathrm{P})$, which has been widely studied because of its ability to induce carcinogenicity and mutagenicity in humans and animals (Anandakumar et al., 2009; Kasala et al., 2015). However, it must be metabolically activated to the B(a)P-7,8-dihydrodiol-9,10-epoxide metabolite (BPDE)

\footnotetext{
*Correspondence: H. Brihoum. Laboratory of Molecular Toxicology, Faculty of Sciences, University of Jijel, 18000 - Jijel, Algeria. Tel/Fax 00 (213) 3450 26 87. E-mail: brihoum_hadjer@yahoo.fr
}

before exerting its toxic effects. BPDE is considered the ultimate and most carcinogenic derivative of $\mathrm{B}(\mathrm{a}) \mathrm{P}$ metabolism, as it reacts with DNA as well as the redox cycling of $\mathrm{B}(\mathrm{a}) \mathrm{P}$-quinone and produces reactive oxygen species (ROS) (Briede et al., 2004).

Therefore, it is necessary to develop more effective curative or preventive therapies with few side effects to significantly reduce lung cancer mortality. Several studies have reported the efficacies of different natural products for treating lung cancer, such as use of propolis, as their therapeutic potential to treat several diseases is well shown (Banskota, Tezuka, Kadota, 2001).The chemical composition of propolis or bee glue is very complex and varies according to geographical origin, the bee species, (Kurek-Górecka et al., 2014), and the trees and plants in the ecosystem that influence the biological activities of the bees (Piccinelli et al., 2013). Despite differences in origin and chemical composition, different types of propolis have a variety of biological activities, including antioxidant power. It has been suggested that the therapeutic activities of propolis depend mainly on the presence of polyphenols, 
specifically flavonoids (Campos et al., 2015; MouhoubiTafinine, Ouchemoukh, Tamendjari, 2016). At least 38 different flavonoids have been reported in propolis.

Algeria's distinctive climate, fauna, and flora contribute to its great biodiversity (Soltani et al., 2017). According to some studies, Algerian propolis has a wide range of biological properties, including antitumor (Benguedouar et al., 2016), bactericidal (Soltani et al., 2017), renoprotective (Boutabet et al., 2011), and antioxidant activities (Piccinelli et al., 2013; MouhoubiTafinine, Ouchemoukh, Tamendjari, 2016) and it contains several anti-cancer phenolic components (Boutabet et al., 2011).

Epidemiological and preclinical studies have suggested that the polyphenols and flavonoids in propolis possess direct antitumor and chemopreventive effects. This has accentuated cancer prevention strategies in which propolis was used as a dietary supplement (Seydi et al., 2016). The anticarcinogenic activity of the flavonoids in propolis can suppress tumor growth by inhibiting angiogenesis and inducing apoptosis of tumor cells (Szliszka et al., 2011). The protective effect of propolis against several types of cancer, including lung cancer, may occur by directly inhibiting tumor cell growth and inducing apoptosis (Valente et al., 2011) or indirectly by scavenging ROS and increasing antioxidant enzyme activities (Oršolić et al., 2013).

In the present study, we investigated the antitumor effect of Algerian propolis on a human lung adenocarcinoma cell line and its chemopreventive effect in lung cancer induced experimentally by B(a)P for the first time.

\section{MATERIAL AND METHODS}

\section{Material and major reagents}

The A549 human lung adenocarcinoma cell line was obtained from Professor José Luis (UMR_S 911 INSERM, Marseille, France). RPMI, fetal bovine serum (FBS), DPPH, and B(a)P were purchased from SigmaAldrich (St. Louis, MO, USA). Crude propolis was collected from a protected area in Algeria and supplied by a honeybee keeper in the Kaous-Jijel region (Algerian eastern Mediterranean coast) in 2014. The propolis was stored at $4{ }^{\circ} \mathrm{C}$ in airtight/dark containers until analysis.

\section{Preparation of the propolis extract}

The raw propolis was cut into small pieces and added to $95 \%$ ethanol for 2 weeks ( $1 \mathrm{~g}$ in 9 volumes of ethanol) with agitation. After filtration, the filtrate was evaporated at $80^{\circ} \mathrm{C}$ in a rotary evaporator (Evaporator E100; Heidolph Instruments, Schwabach, Germany). The ethanolic extract of propolis (EEP) was resuspsended in 70\% methanol and allowed to steep for 1 night before a second evaporation. The extract was stored in clean, dark, airtight bottles at 4-6 ${ }^{\circ} \mathrm{C}$ until analysis (Alyane et al., 2008).

\section{Cell culture}

The A549 cells were cultured in RPMI supplemented with $10 \%$ FBS containing growth factors, $1 \%$ antibiotics penicillin and streptomycin, and $1 \%$ glutamine. The cells were incubated in $5 \% \mathrm{CO}_{2}$ and $95 \%$ humidity in a $37{ }^{\circ} \mathrm{C}$ incubator. The A549 cells were seeded in $25-\mathrm{cm}^{2}$ culture flasks and grown for 1-2 days before use.

\section{Cytotoxicity of the propolis extract}

The number of viable A549 cells after treatment with the EEP was evaluated by the MTT (3-[4,5-methylthiazol2-yl]-2,5-diphenyl-tetrazolium bromide) assay as described previously (Mosmann, 1983). In brief, A549 cells $\left(1 \times 10^{4}\right.$ cells/well $)$ were seeded in 24 -well microtiter plates in $50 \mu \mathrm{L}$ of RPMI. After a $24 \mathrm{~h}$ incubation (time required for attachment), the medium was renewed with or without different concentrations of the $\operatorname{EEP}(1,5,10$, $20,40,80$, and $100 \mu \mathrm{g} / \mathrm{mL})$. The wells were washed with PBS after 24 and $72 \mathrm{~h}$, and then $100 \mu \mathrm{L} /$ well of the MTT solution $(5 \mathrm{mg} / \mathrm{mL})$ was added. After a $3 \mathrm{~h}$ incubation with MTT at $37^{\circ} \mathrm{C}$, the MTT crystals were solubilized by adding $100 \mathrm{mLDMSO}$ to each well. Absorbance was measured at $550 \mathrm{~nm}$. The percentage cell viability was calculated as follows:

Cell viability $(\%)=$ mean optical density $(\mathrm{OD})$ of treated cells/mean OD of control cells $\times 100 \%$.

The median inhibitory concentration $\left(\mathrm{IC}_{50}\right.$ ) values of the EEP were determined.

\section{Cell adhesion test}

Adhesion assays were performed as described previously (Delamarre et al., 2009). Briefly, 24-well plates were coated with purified extracellular matrix (ECM) protein solutions of fibrinogen ( Fg), collagen type $\mathrm{I}\left(\mathrm{Coll} \mathrm{I}\right.$ ), and polylysine (PL) for $2 \mathrm{~h}$ at $37^{\circ} \mathrm{C}$ and blocked with $0.5 \% \mathrm{PBS} /$ bovine serum albumin. Cells previously preincubated with different concentrations of the EEP $(10,20$, and $40 \mu \mathrm{g} / \mathrm{mL})$ for $30 \mathrm{~min}$ at $37^{\circ} \mathrm{C}$ were added 
to wells and allowed to adhere to the substrata for $2 \mathrm{~h}$ at $37^{\circ} \mathrm{C}$. After washing, the adherent cells were fixed in $1 \%$ glutaraldehyde, stained for 30 min with $0.1 \%$ crystal violet, and lysed with $1 \%$ sodium dodecyl sulfate. Cell adhesion was quantified by measuring absorbance at 600 $\mathrm{nm}$ with a microtiter plate reader.

\section{DPPH free radical scavenging activity}

The free radical-scavenging activity of the test compounds (EEP and quercetin) was investigated according to the method of Brand-Williams, Cuvelier, Berset (1995) and the resulting decrease in DPPH absorption at $517 \mathrm{~nm}$ was measured after $30 \mathrm{~min}$.

\section{Animals}

A total of 24 male albino Wistar rats (weight, $100-200 \mathrm{~g}$ ) were used in this study. The animals were acclimated to polystyrene cages and had free access to food and water. They were randomly divided into three equal groups of eight rats each, and their weight change was followed throughout the treatment period:

Group 1 served as a control and received a single injection of olive oil (B(a)P vehicle); group 2 received, a single dose of B(a)P (200 mg/kg/dissolved in the same vehicle) intraperitoneally (i.p.); and group 3 received the EEP $(25 \mathrm{mg} / \mathrm{kg} /$ day) by gavage for 5 days prior to B(a)P administration. After 5 days, they were injected i.p. with B(a)P (200 mg/kg).

The animals were killed by cervical dislocation after 20 weeks of treatment. The lungs of each rat were collected, washed in $9 \% \mathrm{NaCl}$, weighed, and subjected to macroscopic examination for any signs of inflammation or malignancy. Part of the lung was stored at $-20{ }^{\circ} \mathrm{C}$ until analysis of cellular oxidative stress and the other part was immersed in ethanol-acetic acid-formalin fixative saline (EAFS) for histopathological processing. Blood was collected from the retro-orbital sinus, centrifuged at 3,300 rpm for $10 \mathrm{~min}$, and the serum was collected and frozen for biochemical analyses.

\section{Cytosolic fraction from lung tissue}

A $1 \mathrm{~g}$ portion of pulmonary tissue was homogenized in $3 \mathrm{~mL}$ of phosphate buffer $(0.1 \mathrm{M}, \mathrm{pH} 7.4)$ containing $1.17 \% \mathrm{KCl}$. The homogenate was centrifuged at 2,000 rpm for 15 min at $4{ }^{\circ} \mathrm{C}$ to remove cell debris and then at $12,000 \mathrm{rpm}$ for $30 \mathrm{~min}$. The clear supernatant was used for the biochemical assays (Iqbal et al., 2003).

\section{Assessment of oxidative stress markers}

Malondialdehyde (MDA) was assayed using thiobarbituric acid according to the method described by Ohkawa, Ohishi, Yagi (1979). Total glutathione (GSH) was assayed using the method of Ellman (1959). Superoxide dismutase (SOD) was assessed according to the method of Beauchamp and Fridovich (1971). Glutathione S-transferase activity (GST) was measured using the method of Habig, Pabst, Jakoby (1974) which uses chlorodinitrobenzene as the substrate, and catalase (CAT) activity was assayed by the method of Sinha (1972) based on the disappearance of $\mathrm{H}_{2} \mathrm{O}_{2}$ in the presence of the enzyme source.

\section{Serum samples and marker enzymes}

Serum was used to determine the activities of $\gamma$-glutamyl transpeptidase $(\gamma-\mathrm{GT})$ and lactic dehydrogenase (LDH) employing a kit adapted to an auto analyzer (ECLIA Cobas 411).

\section{Assessment of protein content}

Proteins were measured at all stages according to the Bradford method (Bradford, 1976).

\section{Histopathological study}

After fixing the tissues for $48 \mathrm{~h}$ in EAFS (Harrison, 1984), the lung tissue samples were processed routinely and embedded in paraffin wax to form a paraffin block. Sections of $5 \mu \mathrm{m}$ in thickness were cut and stained with hematoxylin followed by $1 \%$ eosin (H\&E) and examined under a light microscope.

\section{Statistical analysis}

Student's $t$-test was used to assess the statistical significance of the treated groups vs. the control group. $\mathrm{P}$-values $<0.05$ were considered significant.

\section{RESULTS}

\section{Effect of propolis on A549 cell viability}

After treating the A549 cell lines with different concentrations of the EEP, their morphology was abnormal compared to that of the untreated control (data not shown). The MTT assay revealed that A549 cell growth was inhibited after 24 and $72 \mathrm{~h}$ of treatment with the EEP in a dose-dependent manner. The percentage cell viability 
after treatment with the EEP is shown in Figure 1. The $\mathrm{IC}_{50}$ values 24 and $72 \mathrm{~h}$ after treatment for the mean of three independent experiments were 69.94 and $14.32 \mu \mathrm{g} /$ $\mathrm{mL}$, respectively.

\section{Propolis extract affects adhesion of lung tumor cells}

We investigated the possible anti-adhesive activity of the EEP in A549 cells. We performed cell adhesion assays using different purified ECM proteins, such as Fg, Coll I, and PL. As shown in Figure 2, the EEP blocked adhesion of A549 cells to Fg, while no effect was observed for Coll I or PL. This inhibitory action of the EEP on Fg was dose-dependent.

\section{Radical scavenging activity of propolis}

The results of the DPPH scavenging assay compared with those of a reference antioxidant (quercetin) are

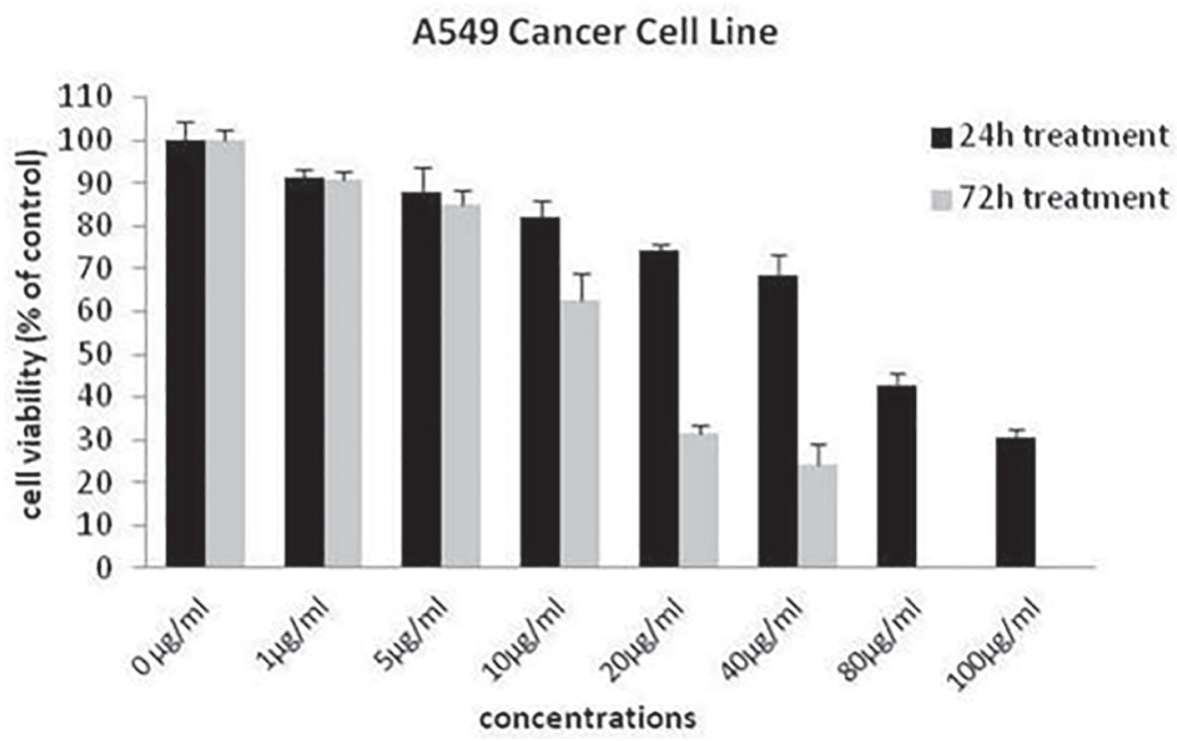

FIGURE 1 - Concentration effectiveness of the Algerian propolis extract on viability of lung carcinoma A549 cells 24 and $72 \mathrm{~h}$ after treatment. Values are mean \pm standard error of three independent experiments.

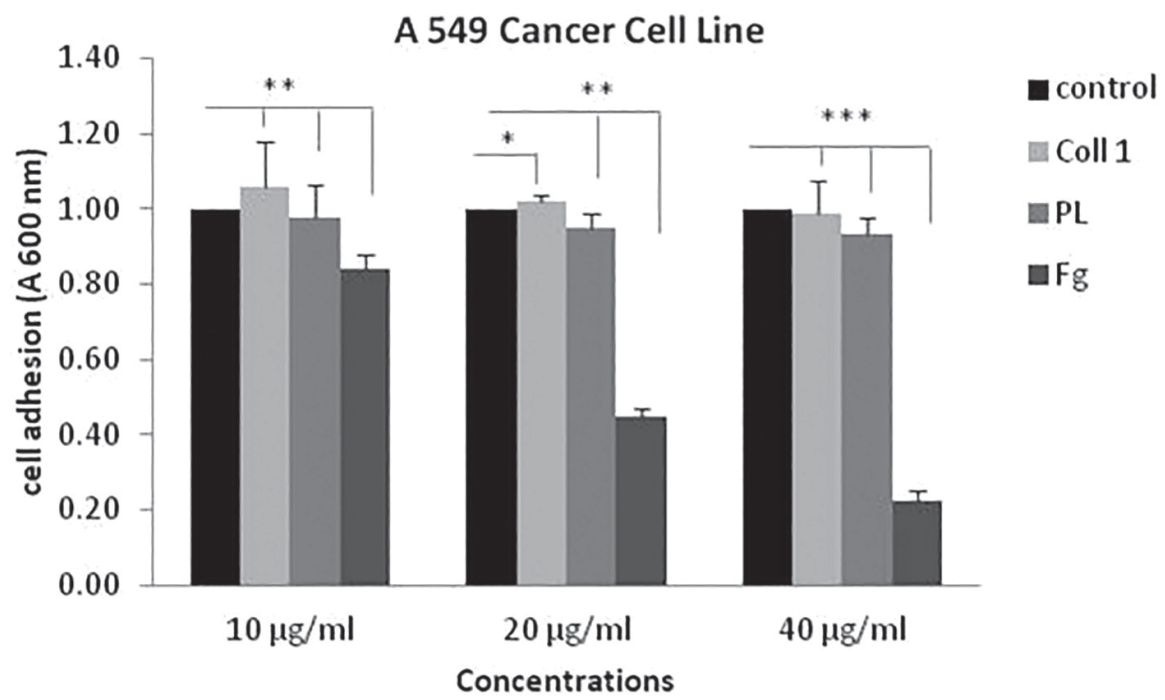

FIGURE 2 - Inhibition of human lung adenocarcinoma cell line (A549) adhesion by the Algerian propolis extract. A 549 cells were pre-incubated with different concentrations of the propolis extract and added to wells coated with $50 \mu \mathrm{g} / \mathrm{mL}$ fibrinogen $(\mathrm{Fg}), 10$ $\mu \mathrm{g} / \mathrm{mL}$ collagen I (Coll I), and $10 \mu \mathrm{g} / \mathrm{mL}$ poly-L-lysine (PL). Values are mean \pm standard error of three independent experiments. p-value $<0.05$ : significant $(*), p<0.01$ : very significant $(* *), p<0.001$ : highly significant $(* * *)$, NS (not significant). 
demonstrated in Figure 3. The EEP reduced the DPPH free radical in a concentration-dependent manner. Strong antioxidant activity was detected at EEP concentrations of $30,75,150,200$, and $300 \mu \mathrm{g} / \mathrm{mL}$, with maximum reactive rates of $41.74,70.67,75.35,85.52$, and $90.73 \%$ respectively. The $\mathrm{IC}_{50}$ values for antioxidant activity of the EEP and quercetin were 43.9 and $54.9 \mu \mathrm{g} / \mathrm{mL}$, respectively.

\section{Effect of propolis on body and lung weight}

Table I presents the effect of the EEP on body and lung weight in the control and experimental groups of animals that were sacrificed at the end of the study. Rats treated with B(a)P (group 2) demonstrated a loss of body weight compared to that in the untreated control rats (group 1). In contrast, lung weight increased significantly $(\mathrm{p}<0.01)$ compared to that of the control group. The EEP significantly $(\mathrm{p}<0.01)$ increased final body weight and significantly $(\mathrm{p}<$ 0.05 ) reduced lung weight in group 3 compared with those in group 2. These data show an observable increase in the relative weights of the lungs in groups 3 and 2, respectively, compared with that in the control group.

\section{Effect of propolis on serum marker enzymes}

Table II presents the effect of the EEP on serum marker enzyme activities in the control and experimental groups. The activities of the marker enzymes LDH and $\gamma \mathrm{GT}$ increased significantly $(\mathrm{p}<0.01)$ in the lung cancerbearing animals (group 2) compared with those in the control group. The EEP treatment (group 3) caused a significant $(\mathrm{P}<0.05 ; \mathrm{P}<0.001)$ decrease in these enzymes activities compared with those in the cancer-bearing group.

\section{Oxidative status}

Five parameters were evaluated to determine the oxidative status of tissues. The assay results of cellular GSH and the enzymatic activities of SOD, CAT, and GST as well as MDA levels in lung tissues of the control and experimental groups are presented in Figure 4.

The rats injected with $\mathrm{B}(\mathrm{a}) \mathrm{P}$ showed a significant increase in MDA levels $(\mathrm{p}<0.001)$ and a significant decrease in GSH $(p<0.001)$, SOD, CAT, and GST activities $(\mathrm{p}<0.01)$ compared with those in the control

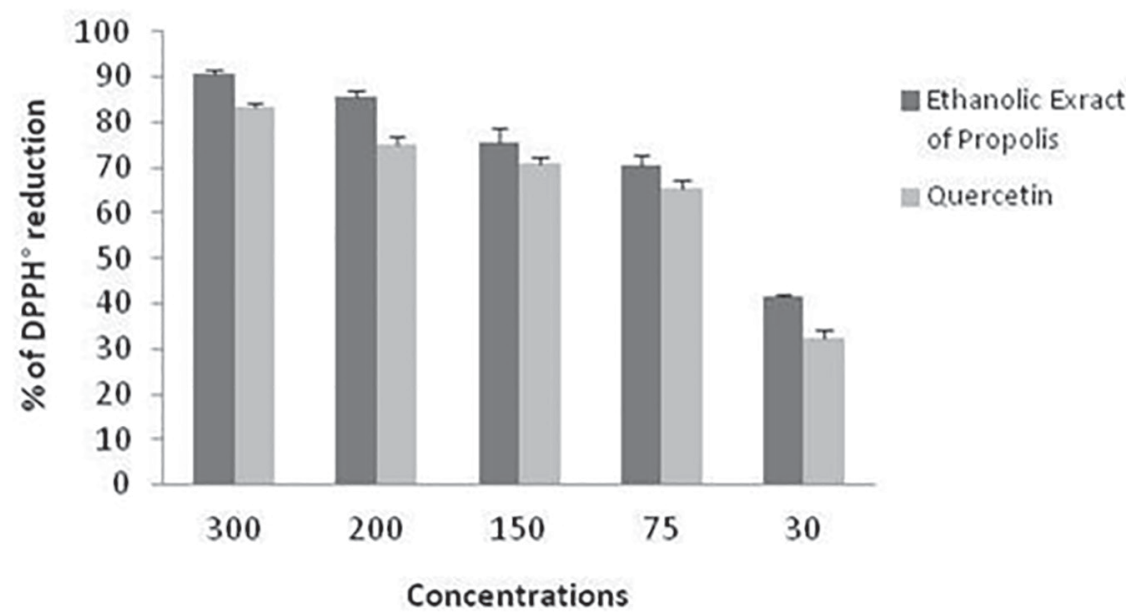

FIGURE 3 - Scavenging effect of the Algerian ethanolic extract of propolis (EEP) vs. quercetin against DPPH free radicals. Each value is expressed as mean \pm standard deviation of three independent experiments.

TABLE I - Effect of administering the ethanolic extract of propolis on the body and lung weight and ratio of lung to body weight in rats

\begin{tabular}{|c|c|c|c|}
\hline Parameters & Group 1 & Group 2 & Group 3 \\
\hline Number of rat examined & 6 & 6 & 6 \\
\hline Body weight (g) & $300 \pm 10$ & $204.53 \pm 21.87^{* *, 1}$ & $246.66 \pm 15.27^{* *, 2}$ \\
\hline Lung weight (g) & $1.15 \pm 0.06$ & $2.31 \pm 0.2^{* *, 1}$ & $1.58 \pm 0.1^{*, 2}$ \\
\hline The relative lung weight (\%) & 0.38 & 1.129 & 0.64 \\
\hline
\end{tabular}

Each value is expressed as mean \pm standard deviation $(\mathrm{n}=6$ /group). P value $<0.05$ : $\operatorname{significant}(*), p<0.01$ : very significant $(* *)$, $\mathrm{p}<0.001$ : highly significant $(* * *)$, NS (not significant), as ${ }^{1}$ group 2 vs. group 1. ${ }^{2}$ group 3 vs. group 2. 
TABLE II - Effect of propolis on serum marker enzyme activities in the control and experimental animals

\begin{tabular}{lccc}
\hline Parameters & Group 1 & Group 2 & Group 3 \\
\hline LDH $(\mu \mathrm{mol} / \mathrm{min} / \mathrm{mg}$ protein) & $1.15 \pm 0.016$ & $3.07 \pm 0.046^{* *, 1}$ & $1.51 \pm 0.076^{*, 2}$ \\
GGT (nmoles/min/mg protein) & $1.938 \pm 0.102$ & $3.414 \pm 0.364^{* * *, 1}$ & $2.574 \pm 0.225^{* * *, 2}$ \\
\hline
\end{tabular}

Each value is expressed as mean \pm standard deviation. $(\mathrm{n}=6$ /group). $\mathrm{p}$-value $<0.05$ : significant $(*), \mathrm{p}<0.01$ : very significant $(* *), p<0.001$ : highly significant $(* * *)$, NS (not significant) as ${ }^{1}$ group 2 vs. group $1 .{ }^{2}$ group 3 vs. group 2 . GGT: $\gamma$-glutamyl transpeptidase. LDH: lactate dehydrogenase

group. MDA was significantly lower $(\mathrm{p}<0.05)$ in group 3 compared with that in group 2, whereas and SOD, CAT, and GSH activities increased significantly $(\mathrm{p}<0.01)$. The enzymatic antioxidants (SOD, CAT, and GST) and non-enzymatic antioxidants (GSH) were enhanced after the EEP treatment compared with those in the carcinogeninduced lung cancer group 2, which was associated with a decrease in MDA level.

\section{Histopathological study}

A macroscopic examination of the lungs of the control rats showed an intact structure, compared with the lungs of rats treated with B(a)P alone. Lungs from rats treated with $\mathrm{B}(\mathrm{a}) \mathrm{P}$ were dark in color possibly due to necrosis and merged pulmonary lobules; however, the lungs treated with the EEP appeared less toxic (data not shown).

The lungs of the control rats showed normal histological structure under the microscope (Figure 5). However, the alveoli were destroyed and intraparenchymal lymphocyte infiltration was detected with formation of a follicle in the B(a)P group. However, administration of EEP significantly decreased intraparenchymal lymphocyte and macrophage infiltration compared with that in the B(a)P group.

\section{DISCUSSION}

One of the strategies to fight cancer is the use of natural products. The incidence of cancer is less common in people whose diet is based on fruits and vegetables. Results from several studies indicate that propolis, as a natural product, and its components has anti-proliferative and anti-neoplastic properties. In the present study, we showed that Algerian propolis decreased cell viability by exerting a cytotoxic effect on A549 human lung adenocarcinoma cells. The antiproliferative and cytotoxic effects of the EEP occurred in a dose-dependent manner. Our results are in accordance with those of Friõn-Herrera et al. (2015), who showed that Brazilian propolis inhibits the growth of A549 cells in a dose-dependent manner and that propolis shows selectivity toward tumor cells compared to normal cells. The $\mathrm{IC}_{50}$ at $72 \mathrm{~h}$ of the EEP was $14.32 \mu \mathrm{g} / \mathrm{mL}$, which is less than that of Brazilian propolis (Friõn-Herrera et al., 2015) and propolis from Thailand (Khacha-Ananda et al., 2013) with $\mathrm{IC}_{50}$ values of 69.17 and $85.05 \mu \mathrm{g} / \mathrm{mL}$, respectively, These results indicate that the Algerian EEP was more toxic against cancer cells than many other propolis, and that inhibition of cancer cell growth may be related to flavonoid content depending on the geography and source of propolis which affect their composition.

Because angiogenesis is an essential process for cancer progression, we evaluated the capacity of propolis to exert anti-adhesive activity using purified ECM proteins, such us the integrin-dependent substratum. ECM proteins are a potential target for pharmacological agents in the treatment of tumor malignancies with the aim to control metastatic spread (Akalu, Cretu, Brooks, 2005). Taken together, our results show that EEP from Algeria notably blocked adhesion of A549 cells to Fg suggesting that the effect of our propolis may involve the integrin family of adhesion receptors and that all integrins are not likely affected because inhibition was not observed by Coll I thereby supporting the findings of Benguedouar et al. who showed that galangin, one of the most abundant flavonoids in our Algerian propolis, reduces the expression of many integrins that play a key role regulating both mitogenic signaling, cell adhesion, and cell migration. Galangin of Algerian propolis induces melanoma cell autophagy/apoptosis dose dependently by activating p38 mitogen activated protein kinase and inhibiting in vivo tumor growth and metastasis in a mice melanoma model (Benguedouar et al., 2016). The same authors showed the importance of both caffeic acid and its derivatives, i.e., CAPE and (+)-chicoric acid methyl ester, present in Algerian propolis for their antioxidant and anticancer properties (Benguedouar et al., 2016; Segueni et al., 2011). Previous studies have shown that CAPE effectively suppresses transforming growth factor (TGF)- $\beta$-enhanced cell motility and TGF- $\beta$-induced Akt 

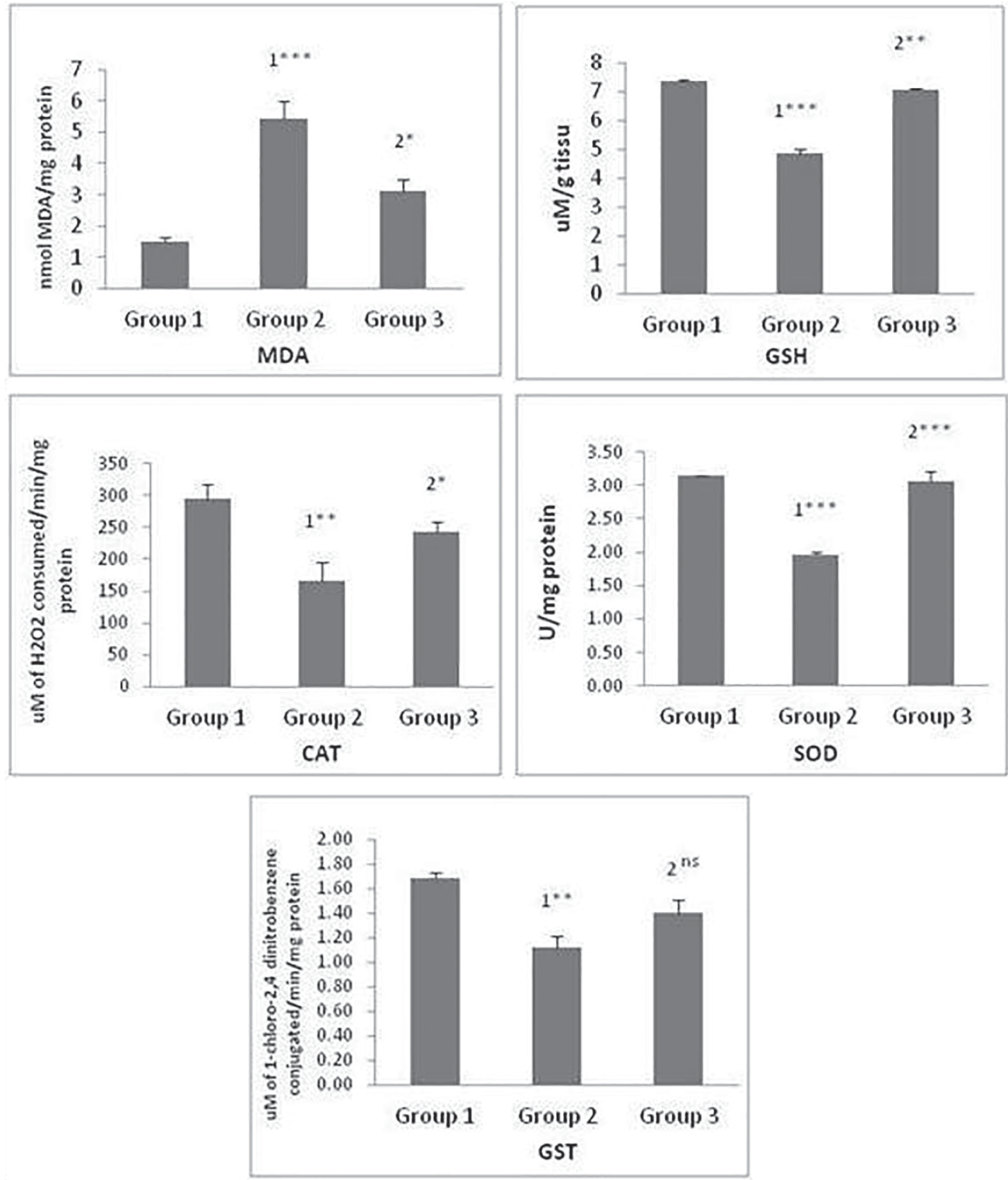

FIGURE 4 - Effect of the Algerian propolis extract on oxidative stress parameters. Each value is expressed as mean \pm standard deviation ( $\mathrm{n}=8$ /group). $\mathrm{p}$-value $<0.05$ : significant $(*), \mathrm{p}<0.01$ : very significant $(* *), \mathrm{p}<0.001$ : highly significant $(* * *)$, NS (not significant). ${ }^{1}$ group 2 vs. group $1 .{ }^{2}$ group 3 vs. group 2. Group 1: control group includes rats that received olive oil; group 2: rats treated with benzo(a)pyrene (B(a)P), Group 3: rats that received the Algerian propolis extract followed by B(a)P. MDA: malondialdehyde, GSH: reduced glutathione, CAT: catalase, SOD: superoxide dismutase, and GST: glutathione s-transferase

(protein kinase $\beta$ ) activation as well as specifically inhibits the phosphatidylinositol 3-kinase)/Akt pathway (Ozturk et al., 2012). Furthermore, treatment of several cancer cell types with CAPE inhibits nuclear factor-kappa B activity (Akyol et al., 2013). In addition, caffeic acid and its derivatives can significantly inhibit UVA-mediated matrix metalloproteinase- 3 upregulation by fibroblasts.
Further study on the antiproliferative activity of the EEP on the A549 cell line should be performed to elucidate the mechanism of anticancer activity.

Oxidative stress is responsible for the occurrence of a wide variety of human diseases, such as cancers (Sosa et al., 2012). Several studies have suggested that propolis possesses cancer chemopreventive activity. We 


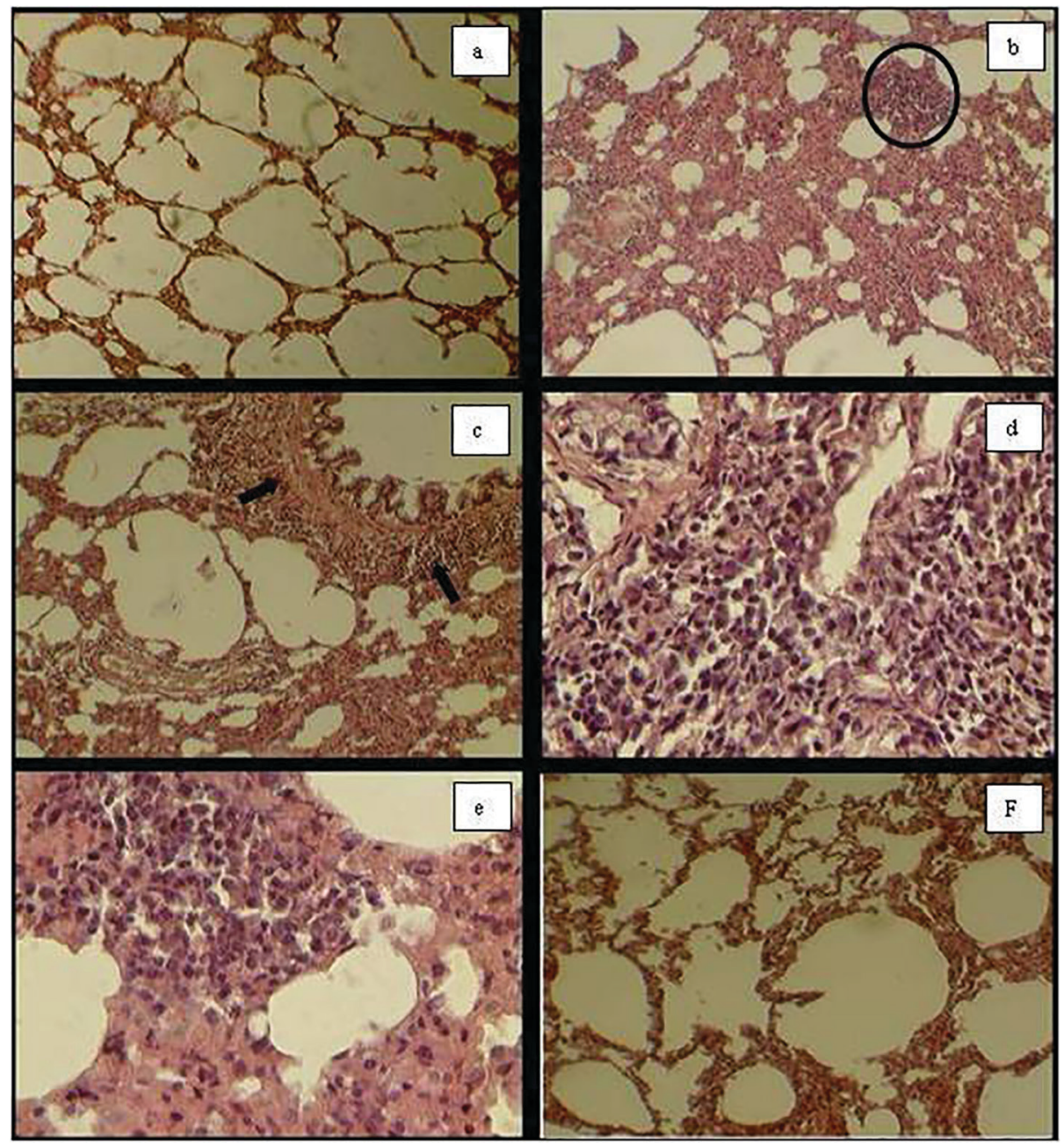

FIGURE 5 - The histopathological studies of lung sections viewed under a light microscope (hematoxylin and eosin [H\&E] staining) in the control and experimental groups. (a) Control animals showing normal architecture with regular sized alveolar spaces (100× $\mathrm{H} \& \mathrm{E})(\mathrm{b})$ and (c) Benzo(a)pyrene (B(a)P)-induced animals showing condensed architecture with destroyed alveoli, alveolar septal thickening, airway inflammation, and hyperchromatic nuclei in alveolar wall cells (100× H\&E (d) and (e) higher magnification shows infiltration of inflammatory cells $(400 \times \mathrm{H} \& \mathrm{E})(\mathrm{F})$ Propolis pre-treated cancer-bearing animals showing slightly reduced alveolar damage compared to that of control animals $(100 \times \mathrm{H} \& \mathrm{E})$. Arrows indicate peribronchial inflammatory infiltration and circles indicate intense alveolar septal infiltration.

were interested in this part in our study to evaluate the antioxidant capacity of the EEP.

In our study, the considerable weight loss observed in animals treated with B(a)P, probably occurred because of cancer cachexia, anorexia, or malabsorption due to the toxic effect of drug reactive metabolites. Moreover, the significant increase in tumorigenesis observed in the lung could be due to uncontrolled proliferation of cancerous cells. Our findings are in agreement with Kasala et al. (2016) who reported that decreases in body weight and increases in lung weight are a common symptom of $\mathrm{B}(\mathrm{a})$ $\mathrm{P}$-induced lung carcinogenesis. The increase in body weight and the decrease in lung weight that we observed after administration of the EEP could be because of the protective efficacy of this extract before drug treatment.

Analysis of tumor marker enzymes, such as GGT and $\mathrm{LDH}$, serves as a proxy of the cancer response to therapy and are indicators of lung damage. GGT activity is a specific marker for diagnosis and also has extrapolative value in malignancies, such as lung cancer, whereas LDH is a fairly sensitive marker for solid neoplasms. Cells of lung cancer-bearing mice express increased levels of GGT and LDH in serum (Anandakumar et al., 2009). In the present study, significant increases in these two tissue marker enzymes were observed in the B(a)P-treated animals. The EEP pre-treatment brought down the levels of these marker enzymes close to normal, suggesting its beneficial effect. 
The antioxidant activities of the EEP were studied in vitro using the DPPH method. Compared to quercetin, a strong and well-known antioxidant used as a positive control, the EPP showed a high scavenging effect. Our results are in agreement with Piccinelli et al. (2013) who reported that different Algerian propolis samples possess strong antioxidant activity with an $\mathrm{IC}_{50}$ range of 32.3-82.5 $\mu \mathrm{g} / \mathrm{mL}$. A positive correlation was detected between the flavonoid content of the propolis and its antioxidant activity. This antioxidant activity is due to the presence of certain elements in the flavonoid structure, such the presence of a double bond between C-2 and C-3 in the $\mathrm{B}$ ring and the presence of highly reactive hydroxyl groups (3' and 4'-dihydroxy) in the ring, which is capable of donating an electron and hydrogen to ROS; thus, interrupting the free radical propagation reaction leading to lipid peroxidation (LPO) (Kurek-Górecka et al., 2014).

In our study, the B(a)P treatment produced large quantities of free radicals, which, in turn, interacted with membrane lipids and consequently induced LPO in the lung tissues of rats. Progressive cellular architectural changes due to oxidative stress and LPO generated during the cytochrome p450 (CYP1A1)-dependent metabolism of $\mathrm{B}(\mathrm{a}) \mathrm{P}$ has been implicated in the pathogenesis of lung carcinogenesis. The products of LPO include MDA, which is involved in the formation of tumors by interacting with DNA to form MDA-DNA adducts, that induce genetic alterations and inhibit protective enzymes, leading to carcinogenesis during B(a)P-induced oxidative stress (Kim, Lee, 1997). Many studies have demonstrated the protective effects of polyphenols in propolis, such as chrysin and CAPE, against oxidative damage in the lungs of rats, which suppress LPO and inhibit lipoxygenase activity (Yildiz et al., 2008; Kasala et al., 2016). This result agrees with our results in which MDA concentration was inhibited in the group treated with B(a)P, which was added after the EEP treatment, and confirms the antioxidant and free-radical scavenging activity of our EEP in reducing the deleterious effects of $\mathrm{B}(\mathrm{a}) \mathrm{P}$.

Another important detoxification pathway consists of the conjugation of $\mathrm{B}(\mathrm{a}) \mathrm{P}$ metabolites with GSH by GSTs, including GST-a, GST-p, and GST-m. ElKhawaga et al. (2003) reported that administration of propolis is accompanied by increased oxidant status as the concentration of GST increases, but which decreases significantly in cancer-bearing mice (El-Khawaga, Salem, Elshal, 2003). These results agree with those obtained in our study where we found a significant increase in the GST level after administering the EEP.

Some studies have reported that a depletion of nonenzymatic antioxidants, such as GSH, is probably due to consumption and utilization by lung cells in conjugation reactions with $\mathrm{BPDE}$, the ultimate carcinogenic metabolites of $\mathrm{B}(\mathrm{a}) \mathrm{P}$, as well as the products of LPO and $\mathrm{H}_{2} \mathrm{O}_{2}$ (Rahman, Macnee, 1999), which oxidize GSH sulfhydryl groups to the disulfide compound GSSG (oxidized form), leading to their depletion. The current study shows that the EEP increased and normalized the depleted level of GSH caused by B(a)P. Studies have also reported that administration of some of the flavonoids found in propolis can increase GSH levels (Al-Jasabi, Abdullah, 2013; Kasala et al., 2016) which serves as free radical scavenger by neutralizing the hydroxyl radicals via donation of a hydrogen atom (Deponte, 2013).

Conversion of ROS to less toxic intermediates by enzymatic antioxidants, such SOD and CAT, represents another important detoxification pathway against oxidative damage induced by B(a)P. The main function of SOD is to protect the cell from oxidative damage caused by superoxide anions and LPO, whereas that of CAT is to catalyze the breakdown of $\mathrm{H}_{2} \mathrm{O}_{2}$ generated during oxidative stress in tumor cells. Decreased SOD and CAT activities are observed in lung cancer (Kasala et al., 2016) and could be related to increased oxidative damage to DNA and proteins or to the accumulation of superoxide anions and $\mathrm{H}_{2} \mathrm{O}_{2}$ which consumes these enzymes. We observed that treatment with the EEP significantly reversed all changes induced by $\mathrm{B}(\mathrm{a}) \mathrm{P}$ by increasing SOD and CAT.

In line with the present results, it has been reported that some components of propolis, such as CAPE, have a regulatory effect on activities of antioxidant enzymes, such as CAT, SOD, and GSH. Moreover, administering CAPE to rats modifies the enzyme activity of CYP P450 isoforms such us CYP1A1 (Akyol et al., 2016), which are involved in activating of $\mathrm{B}(\mathrm{a}) \mathrm{P}$.

Our findings show that the chemopreventive efficacy of the EEP against B(a)P-induced progression of lung tumorigenesis may be due, in part, to inhibiting LPO and inducing antioxidant activity to quench ROS-mediated oxidative stress, which in turn maintains the cellular oxidant/antioxidant balance and protects against oxidative damage exerted by B(a)P. A histopathological study of lung tissue from each group was performed to substantiate the enhanced effect of the EEP.

\section{CONCLUSION}

The EEP inhibited proliferation of A549 cancer cells and revealed anti-adhesive activity by the integrin family of adhesion receptors. Furthermore, histological and biochemical studies of lung tissues showed that the EEP markedly reduced oxidative stress caused by $\mathrm{B}(\mathrm{a}) \mathrm{P}$ 
and prevented damage by increasing enzymatic and nonenzymatic antioxidants, as well as decreasing LPO. These results suggest that Algerian propolis can act against lung cancer, and may lead to the potential use of these natural compounds for treating and preventing lung cancer.

\section{REFERENCES}

Akalu A, Cretu A, Brooks PC. Targeting integrins for the control of tumour angiogenesis. Expert Opin Investig Drugs. 2005;14(12):1475-86.

Akyol S, Ozturk G, Ginis Z, Armutcu F, Yigitoglu MR, Akyol $\mathrm{O}$. In vivo and in vitro antıneoplastic actions of caffeic acid phenethyl ester (CAPE): therapeutic perspectives. Nutr Cancer. 2013;65(4):515-526.

Akyol S, Gulec MA, ErdemLi HK, Akyol O. Can propolis and caffeic acid phenethyl ester be promising agents against cyclophosphamide toxicity? J Intercult Ethnopharmacol. 2016;5(1):105-7.

Al-Jasabi S, Abdullah MS. The role of antioxidant hesperidin in the attenuation of lung cancer caused by benzo[a] pyrene in balb/c mice. World Appl Sci J. 2013;22(8):1106-10.

Alyane M, Kebsa W, Boussenane HN, Rouibah H, Lahouel M. Cardioprotective effects and mechanism of action of polyphenols extracted from propolis against doxorubicin toxicity. Pak J Pharm Sci. 2008;21(3):201-209.

Anandakumar P, Kamaraj S, Ramakrishnan G, Jagan S, Devaki T. Chemopreventive task of capsaicin against Benzo(a)pyreneinduced lung cancer in Swiss albino mice. Basic Clin Pharmacol Toxicol. 2009;104(5):360-5.

Banskota AH, Tezuka Y, Kadota S. Recent Progress in Pharmacological Research of Propolis. Phyther Res. 2001;15(7):561-71.

Beauchamp C, Fridovich I. Superoxide dismutase: improved assays and an assay applicable to acrylamide gels1. Anal Biochem. 1971;44(1):276-87.

Benguedouar L, Lahouel M, Gangloff S, Durlach A, Grange $\mathrm{F}$, Bernard P, et al. Ethanolic extract of algerian propolis and galangin decreased murine melanoma T. Anti-Cancer Agents Med Chem. 2016;16(9):1172-83.
Boutabet K, Kebsa W, Alyane M, Lahouel M. Polyphenolic fraction of Algerian propolis protects rat kidney against acute oxidative stress induced by doxorubicin. Indian J Nephrol. 2011;21(2):101-6.

Bradford MM. A rapid and sensitive method for the quantitation microgram quantities of protein utilizing the principle of proteindye binding. Anal Biochem. 1976;72(1-2):248-54.

Brand-Williams W, Cuvelier ME, Berset C. Use of a free radical method to evaluate antioxidant activity. LWT - Food Sci Technol. 1995;28(1):25-30.

Briede JJ, Godschalk RW, Emans MT, De Kok TMC, Van Agen E, Van Maanen JM, et al. In vitro and in vivo studies on oxygen free radical and dna adduct formation in rat lung and liver during benzo[a]pyrene metabolism. Free Radic Res. 2004;38(9):9951002 .

Campos JF, Santos UPD, Rocha PDS, Damião MJ, Balestieri JBP, Cardoso CAL, et al. Antimicrobial, antioxidant, antiinflammatory, and cytotoxic activities of propolis from the stingless bee tetragonisca fiebrigi (Jataí). Evid-Based Complement Altern Med. 2015;2015:1-11.

Delamarre E, Taboubi S, Mathieu S, Bérenguer C, Lissitzky J, Figarella-branger D, et al. Expression of Integrin $\alpha 6 \beta 1$ enhances tumorigenesis in glioma cells. Am J Pathol. 2009;175(2):844-55.

Deponte M. Glutathione catalysis and the reaction mechanisms of glutathione-dependent enzymes. Biochim Biophys Acta J. 2013;1830(5):3217-66.

El-Khawaga O-AY, Salem T, Elshal MF. Protective role of Egyptian propolis against tumor in mice. Clin Chim Acta. 2003;338(1-2):11-6.

Ellman GL. Tissue sulfhydryl groups. Arch Biochem Biophys. 1959;82(1):70-7.

Friõn-Herrera Y, Díaz-García A, Ruiz-Fuentes J, RodríguezSánchez H, Sforcin JM. Brazilian green propolis induced apoptosis in human lung cancer A549 cells through mitochondrial-mediated pathway. J Pharm Pharmacol. 2015;67(10):1448-56.

Habig WH, Pabst MJ, Jakoby WB. Glutathione S-Transferases. J Biol Chem. 1974;249(22):7130-9. 
Harrison PTC. An ethanol-acetic acid-formol saline fixative for routine use with special application to the fixation of nonperfused rat lung. Lab Anim. 1984;18(4):325-31.

Iqbal M, Sharma SD, Okazaki Y, Fujisawa M, Okada S. Dietary supplementation of curcumin enhances antioxidant and phase ii metabolizing enzymes in ddy male mice : possible role in protection against chemical carcinogenesis and toxicity. Pharmacol Toxicol. 2003;92(1):33-8.

Kasala ER, Bodduluru LN, Barua CC, Sriram CS, Gogoi R. Benzo(a)pyrene induced lung cancer: Role of dietary phytochemicals in chemoprevention. Pharmacol Rep. 2015;67(5):996-1009.

Kasala ER, Bodduluru LN, Barua CC, Madhana RM, Dahiay V, Budhani MK, et al. Chemopreventive effect of chrysin, a dietary flavone against benzo ( a ) pyrene induced lung carcinogenesis in Swiss albino mice. Pharmacol Reports. 2016;68(2):310-8

Khacha-Ananda S, Tragoolpua K, Chantawannakul P, Tragoolpua Y. Antioxidant and anti-cancer cell proliferation activity of propolis extracts from two extraction methods. Asian Pac J Cancer Prev. 2013;14(11):6991-5.

Kim KB, Lee BM. Oxidative stress to DNA, protein, and antioxidant enzymes (superoxide dismutase and catalase) in rats treated with benzo(a)pyrene. Cancer Lett. 1997;113(12):205-12.

Kurek-Górecka A, Rzepecka-Stojko A, Górecki M, Stojko J, Sosada M, Swierczek-Zieba G. Structure and antioxidant activity of polyphenols derived from propolis. Molecules. 2014;19(1):78-101.

Mosmann T. Rapid colorimetric assay for cellular growth and survival : application to proliferation and cytotoxicity assays. $\mathrm{J}$ Immunol Methods. 1983;65(1-2):55-63.

Mouhoubi-Tafinine Z, Ouchemoukh S, Tamendjari A. Antioxydant activity of some algerian honey and propolis. Ind Crop Prod. 2016;88:85-90.

Ohkawa H, Ohishi N, Yagi K. Assay for lipid peroxides in animal tissues thiobarbituric acid reaction. Anal Biochem. 1979;95(2):351-8.

Oršolić N, Car N, Lisičić D, Benković V, Knežević AH ĐD, Petrik J. Synergism between propolis and hyperthermal intraperitoneal chemotherapy with cisplatin on Ehrlich ascites tumor in mice. J Pharm Sci. 2013;102(12):4395-405.
Ozturk G, Ginis Z, Akyol S, Erden G, Gurel A, \& Akyol O. The anticancer mechanism of caffeic acid phenethyl ester (CAPE): review of melanomas, lung and prostate cancers. Eur Rev Med Pharmacol Sci. 2012;16(15):2064-2068.

Piccinelli AL, Mencherini T, Celano R, Mouhoubi Z, Tamendjari A, Aquino RP, et al. Chemical composition and antioxidant activity of algerian propolis. J Agric Food Chem Two. 2013;61(21):5080-8.

Rahman I, Macnee W. Lung glutathione and oxidative stress: implications in cigarette smoke-induced airway disease. Am J Physiol Lung Cell Mol Physiol. 1999;277(6 Pt 1):1067-88.

Segueni N, Magid AA, Decarme M, Rhouati S, Lahouel M, Antonicelli F, Lavaud C, Hornebeck W. Inhibition of stromelysin-1 by caffeic acid derivatives from a propolis sample from Algeria. Planta medica. 2011;77(10):999-1004.

Seydi E, Hosseini SA, Salimi A, Pourahmad J. Propolis induce cytotoxicity on cancerous hepatocytes isolated from rat model of hepatocellular carcinoma: Involvement of ROS-mediated mitochondrial targeting. PharmaNutrition. 2016;4(4):143-50.

Siegel RL, Miller KD, Jemal A. Cancer Statistics, 2015. CA Cancer J Clin. 2015;65(1):5-29.

Silva BAK, Silva IS, Pereira DM, Aydos RD, Carvalho PDTC, Facco GG. Experimental model of pulmonary carcinogenesis in Wistar rats. Acta Cir Bra. 2007;22(Suppl 1):16-20.

Sinha AK. Colorimetric assay of catalase. Anal Biochem. 1972;47(2):389-94.

Soltani E, Cerezuela R, Charef N, Mezaache-Aichour S, Esteban MA, Zerroug MM. Algerian propolis extracts: Chemical composition, bactericidal activity and in vitro effects on gilthead seabream innate immune responses. Fish Shellfish Immunol. 2017;62:57-67. issue number is missing

Sosa V, Moliné T, Somoza R, Paciucci R, Kondoh H, LLeonart ME. Oxidative stress and cancer : an overview. Ageing Res Rev. 2012;12(1):376-90.

Szliszka E, Zydowicz G, Janoszka B, Dobosz C, KowalczykZiomek G, Krol W. Ethanolic extract of Brazilian green propolis sensitizes prostate cancer cells to TRAIL-induced apoptosis. Int J Oncol. 2011;38(4):941-53. 
Valente MJ, Baltazar AF, Henrique R, Estevinho L, Carvalho M. Biological activities of Portuguese propolis: protection against free radical-induced erythrocyte damage and inhibition of human renal cancer cell growth in vitro. Food Chem Toxicol. 2011;49(1):86-92.

Yang Z, Zhuan B, Yan Y, Jiang S, Wang T. Identification of gene markers in the development of smoking-induced lung cancer. Gene. 2016;576(1 Pt 3):451-7.
Yildiz OG, Soyuer S, Saraymen R, Eroglu C. Protective effects of caffeic acid phenethyl ester on radiation induced lung injury in rats. Clin Investig Med Clin Exp. 2008;31(5):242-7.

Received for publication on $04^{\text {th }}$ July 2017 Accepted for publication on $15^{\text {th }}$ September 2017 